\title{
MEŽI LATVIJĀ LAIKU LOKOS UN MEŽA DIENU FENOMENS
}

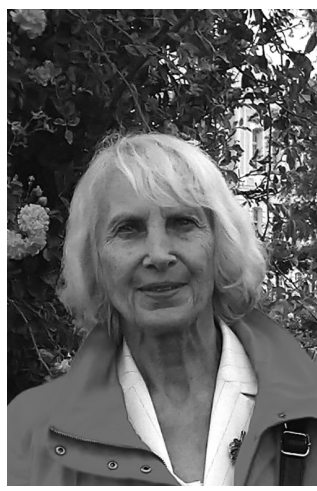

Mudrīte Daugaviete, Dr. sc. ing., Latvijas Valsts mežzinātnes institūta (LVMI) Silava Meža atjaunošanas un ieaudzēšanas pētniecības grupas vadošā pētniece (kopš 2000. gada). Studējusi Latvijas Lauksaimniecības akadēmijas Mežsaimniecības un mežtehnikas fakultātē, iegūstot mežsaimniecības inženiera diplomu. Profesionālo darbību sākusi Vissavienības meliorācijas institūtā kā jaunākā zinātniskā līdzstrādniece lauksaimniecības un meža meliorācijas jautājumos, par šo tēmu ieguvusi lauksaimniecības zinātnes doktora grādu (1975). Darbu turpinājusi LVMI Silava par meža kokaudzētavu lietēšanas režīmu izstrādi, turpinājusi pētījumus par meža atjaunošanas un ieaudzēšanas problēmām meža un neizmantojamās lauksaimniecības zemēs. Ieguvusi inžnierzinātņu doktora grādu (1993). Atziņas par veiktajiem pētījumiem apkopotas divās monogrāfijās un vairāk nekā 180 zinātniskos un populārzinātniskos rakstos. Apbalvota ar Atzinības krustu (2018).
Raksturvārdi: Meža dienas, talkas, meža ieaudzēšana, stādīšana, sēšana.

\section{Latvijas mežu sākotne}

Dabas apstākḷus Latvijā nosaka tās ǵeogrāfiskais izvietojums Austrumeiropas līdzenuma rietumdaḷā. Tādēl vairākas mūsu valsts teritoriālās platības ar līdzenu reljefu bieži ir pakḷautas dažādu gaisa masu plūsmām, kas izraisa straujas laika apstākḷu izmaiṇas. Latvijas augu valsts ir veidojusies îpašās ǵeoklimatiskās krustcelēs, kur vienkopus saplūdušas ziemeḷu-dienvidu un austrumu-rietumu veǵetācijas. Jūras tuvums, kuras piekrastē sastopamas daudzas sugas, kas nav atrodamas dziḷāk iekšzemē; sastopami arī augi - siltā atlantiskā un aukstā boreālā laikmeta relikti, kuru vienlaidu pamatmateriāls pašlaik ir tālu no Latvijas robežām, - un tās ir tikai dažas liecības, kas apstiprina Latvijas augu valsts savdabīgumu ${ }^{1}$.

Vēstures dati liecina, ka pirms apmēram 200 gadu tūkstošiem sākās lielais ledus

\footnotetext{
1 Prieditis 2014.
}

laikmets, kas iznīcināja visu sākotnējo augāju. Pēdējais ledus laikmets beidzās pirms apmēram 16-14 tūkstošiem gadu, tad arī sāka attīstīties mūsu pašreizējais augājs ${ }^{2}$. Apmēram pirms 11 tūkstošiem gadu klimats kḷuva siltāks un visā Latvijas teritorijā sāka ieviesties un izplatīties meži. Maksimumu mežainums sasniedza periodā pirms deviņiem gadu tūkstošiem, kad meži klāja 90\% Latvijas teritorijas³. Pārējās platības aizņēma purvi un upju palieņu pḷavas. Vissiltākais klimats pēcledus laikmeta periodā Latvijā iestājās pirms 7000 gadiem, kad tas bija apmēram par 2,5 grādiem siltāks nekā mūsdienās. Klimats bija arī mitrāks nekā tagad, un mūsu teritorijā sāka ieviesties ezerrieksts (Trapa natans), purvmirte (Myrica gale), parastā īve (Taxus baccata), kā arī izplatîjās platlapju meži, kuros auga daudz vīksnu (Ulmus laevis), ozolu (Quercus robur), lazdu (Corylus avellana) un liepu (Tilia cordata) $)^{4}$.

\footnotetext{
2 Latvijas mežu vēsture 2014.

3 Eihe 1937; Latvijas biotopi 2001.

4 Vītinšs 1925; Strods et al. 1999; Latvijas biotopi 2001; Priedīis 2014.
} 
Apmēram pirms 6000 gadiem platlapju mežu izplatība sasniedza maksimumu. Visā Latvijas teritorijā tolaik bija sastopams arī skābardis (Carpinus betulus) un dižskābardis (Fagus sylvatica). Savukārt pirms aptuveni 4700 gadiem klimats atkal kḷuva vēsāks un sausāks: samazinājās platlapju koku, bet palielinājās egḷu izplatība ${ }^{5}$.

\section{Saimnieciskās darbības un klimata izmaiṇu ietekme uz Latvijas mežu platībām}

Pēc vēstures pētnieku liecībām, saimnieciskā darbība Latvijā aizsākusies jau senā pagātnē, apm. 2000-2500 g. p. Kristus, t. i., akmens laikmetā, kad mūsu valsts teritorijā ienākušas ciltis, kas sākušas intensīvi nodarboties ar līdumu zemkopību, tādējādi izdedzinot lielas meža platības ${ }^{6}$. Tajā laikā tîrumu izveidošanai galvenokārt izraudzītas barības vielām bagātākās augsnes zem platlapju - ozolu un liepu - mežiem. Sākotnēji šīs ciltis apmetušās Kurzemē un Zemgalē, t. i., uz dienvidiem no Ventas, Abavas un Lielupes baseina, bet vēlāk virzījušās tālāk uz ziemel̦iem. Arheolog̣iskie izrakumi liecina, ka meža platības strauji samazinājušās ne tikai saimnieciskās darbības rezultātā, bet arī postījumu dēl, kurus nodarījuši lieli mājdzīvnieku bari. Par to vēsta senās hronikas, un tas īpaši attiecināms uz platlapju, galvenokārt ozolu, mežiem. Turpmākajos gadsimtos ozolkoksne tikusi plaši lietota piḷ, kā arī kug̣u būvniecīibā $\bar{a}^{7}$.

Meža un augšṇu zinātnieki skaidro, ka ne tikai cilvēks vainojams ozolu mežu izzušanā, jo apmēram 2000 gadu ilgā laika posmā ievērojami izmainījies klimats - tas kḷuvis vidēji par $2,5^{\circ} \mathrm{C}$ vēsāks un mitrāks, savukārt no augsnes virskārtas galvenokārt izskalošanās dēl izzudis kalcija karbonāts, bet, izzūdot šai minerālvielai, og̣̣ıskābā gāze, kas rodas, trūdvielām sadaloties, un ko izdala arī augu saknes, atņem absorbēto kaļki māla dạ̦in̄ām un organiskajām vielām. Tādējādi augsne paskābinās, un līdz ar

\footnotetext{
5 Strods 1999.

6 Eihe 1933; Eihe 1935; Eihe, 1937; Latvijas mežu vēsture 2014.

7 Eihe, 1937; Zunde 1999.
}

to platlapju mežu koku augšanai šāds augsnes sastāvs vairs nav piemērots ${ }^{8}$.

M. Galeniece 1935. gadā publicēja pētîjumu par Latvijas mežu un purvu attīstību. Viņa uzskatīja, ka viens no precīzākajiem paņēmieniem augu sastāva izmaiņu noteikšanā ir putekšn, diagrammas, kas iegūstamas, analizējot sūnu purvu kūdras kārtas ${ }^{9}$. Pētījumu rezultāti liecināja, ka jau 1000 g. p. Kristus šādas diagrammas uzrāda egles un bērza klātbūtni, savukārt ozola putekšņlīkne ir ievērojami samazinājusies ${ }^{10}$. Tas nozīmēe, ka teritorijā būtiski ir izmainījies zemsedzes sastāvs: mežu platības sarukušas, bet degumu un nemeža vietās ieviesušās pioniersugas - bērzs, parastā egle, priede u. c. Savukārt arheoloǵiskajos izrakumos noskaidrots, ka jau 400-800 g. p. Kristus, t. i., vidējā dzelzs laikmetā, meža zemes vēl vairāk sarukušas, jo teritorija bijusi vairāk apdzīvota un lauki atmežoti. Kā rakstīja mežzinātnieks V. Eihe, pilnīgi neskarts pirmmežs Latvijas teritorijā vairs nav sastopams. Lielākos zaudējumus mežs cietis no 15 . gs. beigām līdz pat 18. gs. beigām, kad, palielinoties iedzīvotāju skaitam, pieaugušas arī vajadzības pēc koksnes, zemes un uzturā lietojamiem produktiem. Turklāt apjomīgas mežu platības aizgājušas bojā ugunsgrēkos. Tomēr vietās, kur iedzīvotājus iznīcināja kari vai epidēmijas, atkal sāka apmežoties tīrumi un agrāk apdzīvotās teritorijas. Tolaik galvenais augsnes apsaimniekošanas pan̄ēmiens bija līdumu sistēma: vispirms mežs tika nolīsts - galvenokārt to nodedzinot, un iegūtā platība 3-4 vai vairāk gadus intensīvi izmantota kā lauksaimniecības zeme, tad atstāta atmatā, lai atjaunotos mežs, pēc tam atkal atkārtoti nolīsta ${ }^{11}$. Bet vēlākajos gadsimtos, sākot no 11 . gs. un līdz pat 17 . un 18 . gs., līdumu saimniekošanu nomainījis biežāk lietotais zemes izmantošanas veids, t. s. papuvju sistēma, kad augsne vienu gadu tika apstrādāta un trīs gadus atstāta papuvē, tāpēc mežs no aramzemes izzudis pavisam ${ }^{12}$. Minētajos gadsimtos notikusi arī gandrīz pilnīga platlapju koku

\footnotetext{
8 Vītinš 1925; Jurēvičs 1931.

9 Galeniece 1935; Eihe, 1937; Galeniece et al. 1958.

10 Galeniece 1935.

11 Eihe 1937.

12 Turpat.
} 


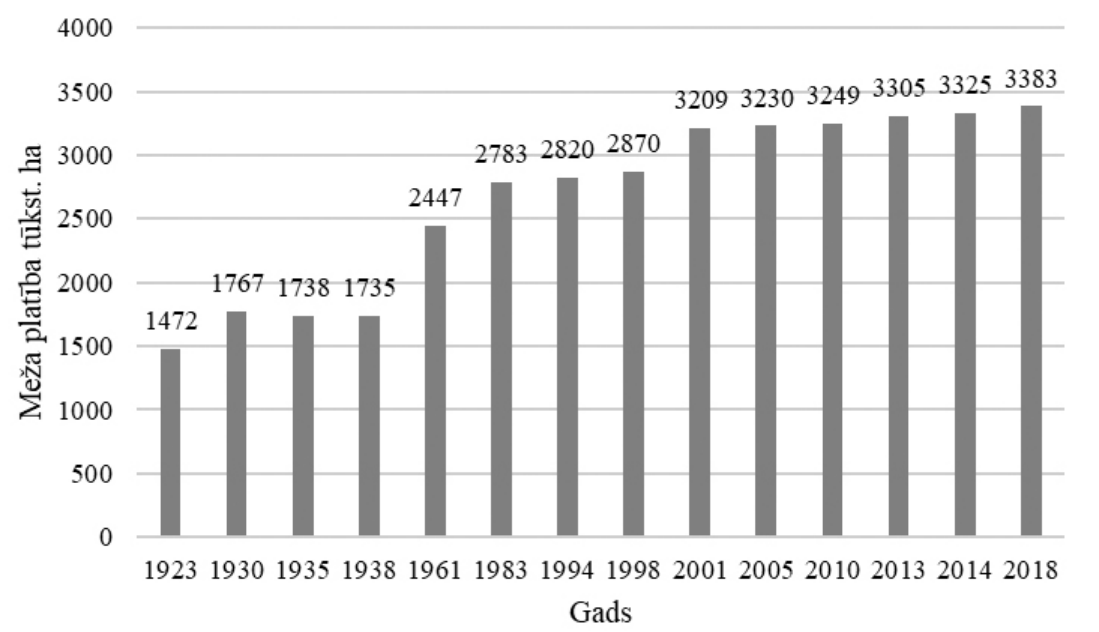

1. attēls. Meža platību dinamika 1923.-2018. gadā. Avots: www.vmd.gov.lv

izciršana, un jau 20. gs. sākumā mežzinātnieku rakstos parādās ziņas, ka ozolu audzes Latvijas teritorijā sastopamas tikai retumis ${ }^{13}$. Saimniekošanas sistēmai kḷūstot racionālākai, pieauga arī nepieciešamība pēc koksnes, īpaši eksporta vajadzībām. Ieviešot plānveida mežsaimniecību, tīrumus mākslīgi apmežoja vai tie apmežojās dabiski ar pioniersugām - priedi, bērzu, retāk apsi ${ }^{14}$. V. Eihe vienlaikus atzina, ka cilvēku ietekme padarījusi Latvijas mežu pēc rakstura vairāk atbilstošu boreālo mežu zonai, nekā tam vajadzētu būt pēc sava ǵeogrāfiskā stāvokḷa, klimata un augsnes īpašīiām. Iznīcinot un vājinot mūsu mežu ekosistēmu, cietušas mazāk izturīgās koku sugas - ozols, osis, kḷava, goba, vīksna, liepa; cilvēka nepārtrauktā ietekme veicinājusi klimata izmaiṇām piemērotāko koku sugu - priedes, parastās egles, bērza uzvaru un pārsvaru. Turpmāk - 19. gs. beigās un 20. gs. sākumā - cilvēka saimnieciskās darbības un karu ietekmē Latvijas teritorijā lielākās platības aizṇēma bijušo muižu un Krievijas cara "kroṇa meži”, savukārt mazākās - pilsētu un komunālo iestāžu meži, kā arī privātmeži ${ }^{15}$. N̦emot vērā atšķirīgos īpašuma veidus, dažāda bijusi arī to apsaimniekošana. Relatīvi labākā

\footnotetext{
13 Vìtinš 1925; Eihe 1937; Jurēvičs 1927; Kiršteins 1936.

14 Reinholds 1935.

15 Vasilevskis 2007.
}

stāvoklī atradušies agrākie "kroṇa meži", jo tajos veiktas pastāvīgas inventarizācijas, ievērota regulētā cirte un saglabātas lielas augstāku vecumklašu audžu platības ar bagātām koksnes krājām ${ }^{16}$. Citādos apstākḷos apsaimniekoti bijušie muižu meži. Pastāvot feodālajai iekārtai, ciršana notikusi, galvenokārt apmierinot muižas un tai piederīgo zemnieku saimniecību vajadzības. Vēlāk, attīstoties kapitālismam, muižu meži kḷuva par primāro ekspluatēšanas objektu un tika nesaudzīgi izcirsti.

Neraugoties uz mežu atjaunošanu, pēc Pirmā pasaules kara to platības Latvijā atkal samazinājās (1. attēls).

Statistikas dati liecina, ka arī 20. gs. 20. gados Latvijas mežu platības vēl turpinājušas sarukt, un 1923. gadā mežainums bija samazinājies līdz 23\% no teritorijas kopplatības (2. attēls).

Mežsaimniecībai, veidojoties kā ienes̄igai biznesa nozarei, radās nepieciešamība pēc meža atjaunošanas. Statistikas dati liecina, ka 1930. gadā Latvijā bijuši ap 500 tūkst. ha krūmiem klātu ganību un stipri noplicinātas lauksaimniecības zemes, kuras vajadzētu apmežot ${ }^{17}$. 


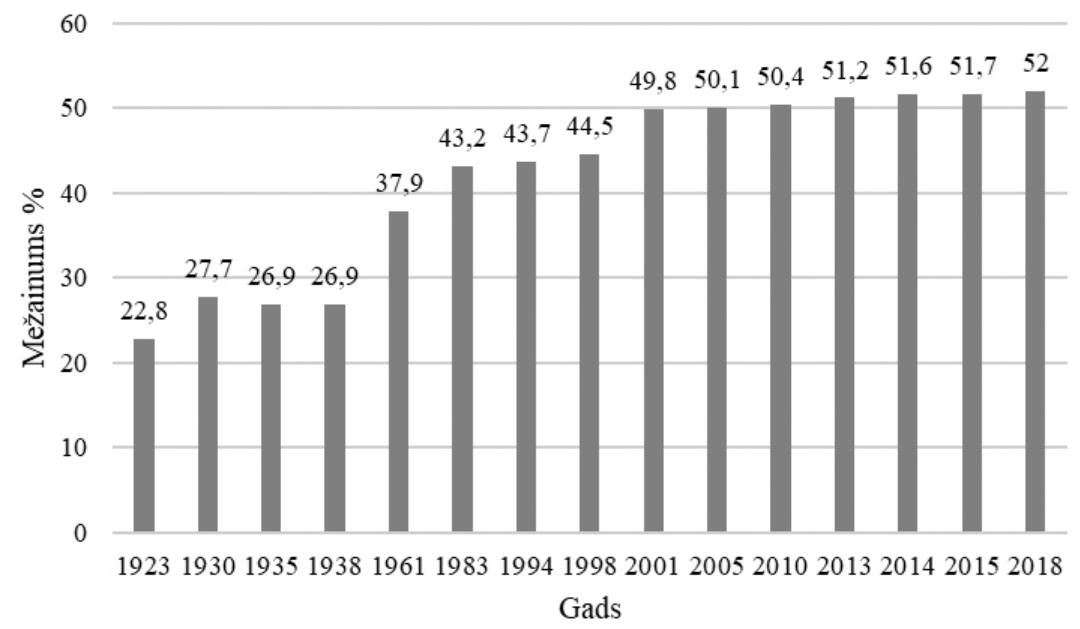

2. attēls. Latvijas mežainuma dinamika 1923.-2018. gadā. Avots: www.vmd.gov.lv

Pēc Otrā pasaules kara, apmežojoties gan dabiski, gan apmežojot lauksaimniecībā neizmantotās zemes, meža platības atkal palielinājās: pēc oficiālās statistikas datiem, jau 1961. gadā tās, salīdzinot ar 1938. gadu, bija palielinājušās par 712 tūkst. ha jeb par $11 \%$. Šobrīd mežainums Latvijā sasniedzis $52 \%$ no visas Latvijas teritorijas. Salīdzinot ar 1994. gadu, kad mainījās agrārās saimniekošanas veids Latvijā, ar mežu apklātā platība palielinājusies par 563 tūkst. ha jeb par 20\%.

\section{Lauksaimniecībā neizmantoto zemju apmežošana un Meža dienu iedibināšana}

Latvijas teritorijā pirmās ziņas par mežu ierīkošanu neauglīgās lauksaimniecības zemēs atrodamas no 18. gs., kad toreizējā Vidzemes lauksaimnieku biedrība bija izsludinājusi konkursu par mežu ierīkošanu neauglīgās zemēs. Par divu pūrvietu neauglīgas zemes apmežošanu un četru gadu aizsargāšanu pienācās 100 rubḷu prēmija. 1824. gadā šo prēmiju saņēma Inciema muižas zemnieks Vāczemnieku Jānis par savas zemes un meža pareizu kopšanu ${ }^{18}$.

\footnotetext{
18 Rudzìtis 1979.
}

Polemika par lauksaimniecības un mežsaimniecības nozīmīgumu Latvijā īpaši saasinājās 20. gs. 20.-30. gados, t. i., pēc Latvijas neatkarības pasludināšanas. Lai veicinātu valsts ekonomisko izaugsmi, šajā laikā īpaša uzmanība pievērsta mežsaimniecības kā l,oti svarīgas tautsaimniecības nozares attīstībai ${ }^{19}$ 1928.-1930. gadā Latvijā iedibinātas Meža dienas. Sākotnēji tajās piedalījušies 20 tūkst. cilvēku, kuri iestādījuši 30 tūkst. koku un krūmu, bet jau 1935. gadā Meža dienu pasākumos iesaistījušies 256 tūkst. cilvēku, kuri iestādījušsi 1,4 milj. koku un krūmu. Valdība sākusi nopietni apspriest apmežošanas jautājumus, un Ministru kabineta lēmumā 1935. gada 30. aprīlī bija norādīts visiem līdzekḷiem sekmēt privāto mežsaimniecību - ar mežu neapklāto platību apmežošanu, gādājot, lai atjaunošanas paņēmieni būtu piemēroti vietējiem apstākliem un tiktu lietoti pēc noteiktiem un pārbaudīitiem principiem, kā arī noskaidrot, kādas platības būtu apmežošanai piemērotas $^{20}$.

No 1921. līdz 1939. gadam neatkarīgās Latvijas valdība veica dažādus pasākumus

\footnotetext{
19 Ozols 1926; Upītis 1931; Reinholds 1933; Ozols 1936; Gross 1936; Ozols 1937; Reinholds 1937; Birnbaums 1937.

20 Birnbaums 1936a.
} 
meža platību palielināšanai un Meža departaments izdeva vairākus rīkojumus: gan par sēklu un stādu izdalīšanu, gan zemes pieškiršanu stādu audzētavām ${ }^{21}$.

Meža departaments 1930. gadā atklāja pirmās Meža dienas Latvijā, uzsākot kampaṇu par meža kā galvenās valsts bagātîbas saglabāšanu un atjaunošanu, praksē demonstrējot meža sēšanas, stādīšanas un kopšanas paṇēmienus, kā arī uzsverot meža saudzēšanas, kopšanas, atjaunošanas nozīmīgumu un pievēršot uzmanību arī dažādu sabiedrisko ēku apkaimes, ceḷu, aleju un lauku māju teritoriju apzaļumošanai ${ }^{22}$.

Ministru prezidents K. Ulmanis, atklājot 1935. gada Meža dienas, aicināja palielināt meža platības: "Arī šogad pēc iespējas plaši jāapmežo lauksaimniecībā nelietojamie zemes gabali, lai uz tiem augtu koki, lai būtu meži, jo koku materiāli un malka visās mājās būs vajadzīgi. Tie, kam meži ir, tie zina, ka meži var dot arī ienākumus. Vislabākais izlietojums būs, ja šī zeme tiks apmežota, ja uz tās augs koki. Šogad lai katrs iestāda vienu bērzu. Mums viscaur neatlaidīgi jāsēj jaunie meži, lai izcirstās vietas nebūtu tukšas un lai apmežotas tiktu visas citādi lauksaimniecībā neizmantojamās zemes. Vislielākā vērība jāpievērš bērziem un melnalkšņiem - taisni tiem kokiem, kas dod mums finierus, malku. ${ }^{\prime 23}$ Atsaucoties uz šo aicinājumu, Latvijas zemnieki visā Latvijā iestādīja bērzu birzis, kuras ir saglabājušās līdz pat mūsu dienām (3. attēls).

No 1934. līdz 1937. gadam Latvijā mākslīgi tika apmežoti 33948 ha, savukārt dabiski apmežoti 38212 ha izcirstajās mežu un lauksaimniecībā neizmantotajās platībās ${ }^{24}$. Statistikas dati liecina, ka tikai 1937. gada Meža dienu laikā apmežoti 242 ha lauksaimniecības zemju, ierīkojot 225 ha skujkoku un 17 ha lapu koku stādījumus ${ }^{25}$.

Arī vēlākajos pirmās Latvijas neatkarības gados lielu vērību pievērsa apkārtnes apzaḷumošanai un ceḷmalu apstādīšanai - 1939. gadā izveidoja ķiršu aleju no Ventspils līdz Lietuvas

\footnotetext{
21 Ozols 1937; Birnbaums 1936.

22 Teikmanis 1931.

23 Ulmanis 1935.

24 Plūmanis 1935; Ozols 1937.

25 Birnbaums 1937.
}

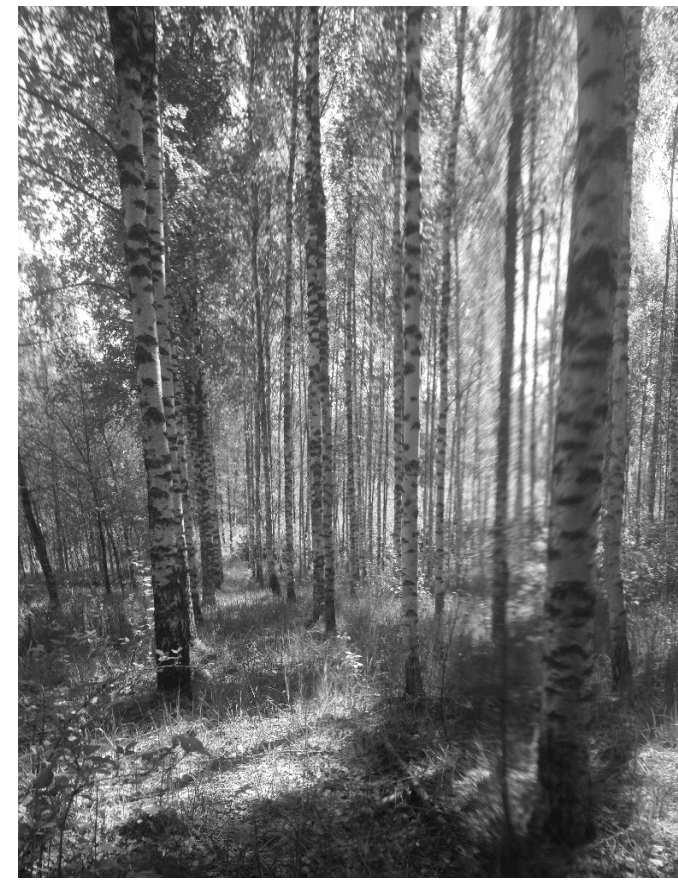

3. attēls. Bērzu birzs Latvijas laukos

robežai, šḳērsojot Lejaskurzemes pagastu teritorijas gar Baltijas jūru. Visā alejas kopgarumā tika iestādīti 16 tūkst. kịšsu stādu ${ }^{26}$. Tāpat tika izveidota Kalpaka aleja no Rīgas caur Saldu un Skrundu līdz Rudbāržiem, stādot ozolus, ošus un liepas ${ }^{27}$. Aleju ierīkošanai izmantoja mežeņus, pārsvarā lapu koku sugas: ozolus, liepas, ošus, gobas, vīksnas, bērzus, pīlādžus, bet no skujkokiem - galvenokārt priedes, egles, lapegles, baltegles ${ }^{28}$ (4. attēls).

Sekmīgi īstenojot valsts politikas uzdevumus, Latvijā notika intensīva izcirsto platîbu apmežošana un mežainums pakāpeniski palielinājās, 1938. gadā sasniedzot jau 28\% no teritorijas kopplatības (2. attēls).

Galvenie meža platību palielināšanas pasākumi Latvijā 18.-20. gs. pirmajā pusē bija 1) kāpu nostiprināšana un apmežošana; 2) lauksaimniecībā neizmantotās zemes apmežošana; 3) aleju ierīkošana.

Tomēr pēc skolota mežu taksatora R. Bruttana atzinuma, 19. gs. un 20. gs. sākumā mežu

\footnotetext{
26 Ozols 1937.

27 Turpat.

28 Teikmanis 1931.
} 


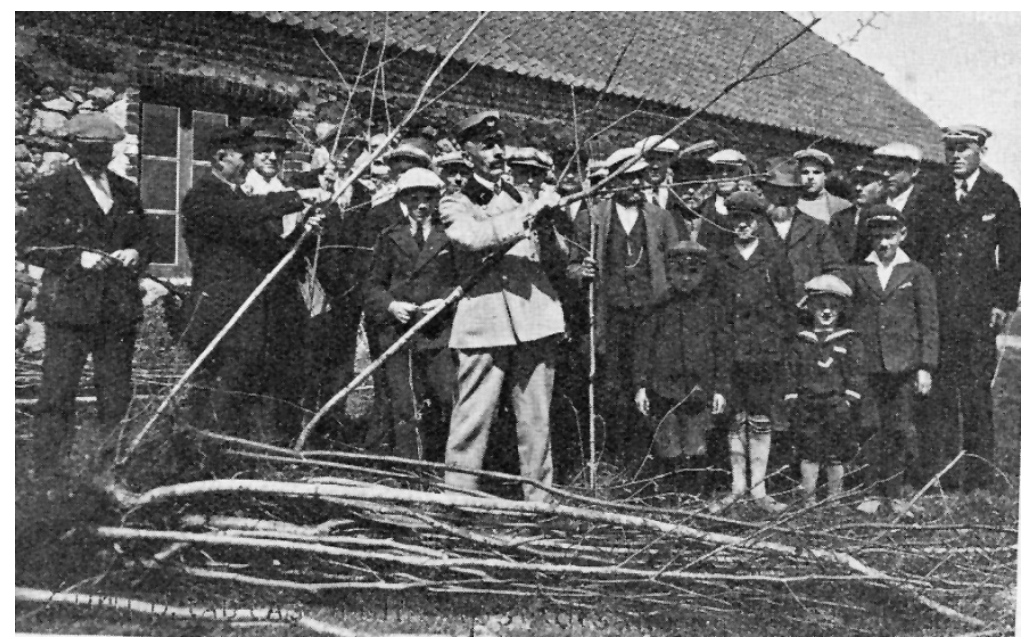

4. attēls. Meža dienas Zūru pagastā: stādīti ozolu un liepu liela izmēra mežeṇi.

Avots: Teikmanis 1931

ieaudzēšanā tīrumu augsnēs tika piel̦autas būtiskas kḷūdas, izvēloties galvenokārt koku sugām nepiemērotus augšņu tipus. Lauksaimniecības zemēs visplašāk stādītā koku suga bijusi priede ${ }^{29}$. Otra lauksaimniecības zemju apmežojumos biežāk stādītā koku suga bija ozols, vēlāk parastā egle. Izmantoja gan parasto, gan ziemel̦u sarkano ozolu (Quercus rubra). Plašus ozolu stādījumus ierīkoja visā Latvijas teritorijā, īpaši tās vidienē, Daugavai pietuvotajos pagastos - Skrīveros, Jumpravā, Krapēe, kāa arī Zemgalē, Kurzemē u. c. Līdz mūsu dienām daḷa šo stādījumu ir saglabājusies, un šobrīd tie jau ir 90-110 un vairāk gadus veci.

20. gs. sākumā mežkopji uzskatīja, ka bērzu stādījumu ierīkošana ir neperspektīiva, jo "par bērzu piln̄igi pietiekošos apmēros gādā pati daba”. Arī melnalkšņu vietā ieteikts stādījumos labāk izmantot osi ${ }^{30}$. Vēlākajos gados, pieaugot pieprasijumam pēc koksnes, jau atzìta bērzu stādījumu atjaunošanas nepieciešamība, galvenokārt, lai nodrošinātu izejvielas finierrūpniecības vajadzībām ${ }^{31}$. Aizsākās pētījumi par bērzu stādu audzēšanu un to ieaugšanos nemeža zemēs ${ }^{32}$.

\footnotetext{
29 Bruttans 1928.

30 Turpat.

31 Roze 1933; Ozols 1936.

32 Roze 1933.
}

Mežizstrādei paplašinoties, 19. gs. otrajā pusē un 20. gs. sākumā neatliekami risināmi bija jautājumi par mežu atjaunošanu. Zinātnieki uzsvēra, ka čiekuru vākšana lauksaimniecības mežu retainēs ir pilnīgi nepieņemams pan̄ēmiens, jo tādējādi notiek slikta g̉enētiskā materiāla pārnese uz nākamajām audzēm ${ }^{33}$. Norādīja, ka ir laiks nopietni pievērsties Latvijas koku selekcijai, lai jaunajos apmežojumos neieviestos mazvērtīgi pēcnācēji, kas pazeminātu nākotnes mežu vērtību. Jau 1932. gadā, apsverot Latvijas tautsaimniecībai izdevīgākos stādīto un dabiski ieaugušo bērzu audžu apsaimniekošanas veidus, par vienu no perspektīvākajiem zinātnieki atzinuši bērzu audzēšanu finierrūpniecības vajadzībām. Augstvērtīgāku bērzu izaudzēšanai ieteikts audzes biezumu samazināt mēreni (tālaika terminologijā: neveikt intensīvu smalctīri un retināšanu), lai saglabātu jaunaudžu biezību 0,9-1,0 ietvaros. Tajā laikā ieteiktais bērzu audžu kopšanas veids ir skrajcirte, kas izpildāma tādā vecumā, kad koki jau ir atzarojušies un izveidojuši slaidus stumbrus ${ }^{34}$.

Pēckara gados jau Padomju Latvijā, mainoties agrārās politikas nostādnēm un ieviešot kolektīvo saimniekošanas sistēmu, sākās

\footnotetext{
33 Roze 1939.

34 Jakobsons 1932; Bērza nozīme un audzēšana, 1934.
} 
lauksaimniecībai nepiemēroto zemju apmežošana. Daḷa šo platību bija jau apmežojušās dabiski, daḷa tika apmežotas, sējot un stādot.

\section{Mežzinātnieku ieguldījums mežaudžu kvalitātes uzlabošanā}

Meža darbinieki un zinātnieki aktīvi iesaistījās topošo mežaudžu ierīkošanā, izvērtěšanā un apsaimniekošanā, kā arī ieteica to uzlabošanai veicamos pasākumus ${ }^{35}$. Nopietniem pētījumiem par parastās priedes, parastās egles, āra bērza, parastās apses, apšu hibrīdu, oša un lapegles audžu augšanas gaitu un apsaimniekošanu pievērsās daudzi meža zinātnieki: A. Kundzin̄š, P. Sarma, P. Maike, K. Sakss, S. Saliņš, J. Smilga, V. Timofejevs, R. Sacenieks, V. Gaross, Dz. Pīrāgs, S. Saliņš, J. Kronītis, J. Bisenieks, A. Kundziņš, J. Matuzānis ${ }^{36}$.

Jauno mežaudžu kvalitātes uzlabošanai tika veikti plaši selekcijas pētījumi, atlasot perspektīvākos klonus un izveidojot sēklu plantācijas: A. Zviedris, J. Gailis, I. Baumanis $^{37}$. Nozīmīgi bija pētījumi par kvalitatīva stādmateriāla izaudzēšanu: M. Bušs, I. Mangalis (2004), I. Igaunis, V. Kāposts, J. Matuzānis.

Plašus pētījumus par Latvijas PSR augšņu tipiem veica K. Brīvkalns (1959). Zinātnieki sāka izstrādāt tehnoloǵijas dažādu augšņu un meža tipu, tostarp purva augšņu un kāpu, apmežošanai: V. Kāposts, V. Gaross, A. Vēveris, J. Kronītis, V. Bambe u. c. ${ }^{38}$

Arī vēlāk - 20. gs. 70.-80. gados - zinātnieki turpinājuši pētîjumus par meža un plantāciju meža ieaudzēšanu lauksaimniecīibā neizmantotajās un atmatā atstātajās lauksaimniecības zemēs, īpaši pievēršoties kvalitatīva sēklu materiāla ieguvei no plūškokiem, izcilām audzēm un sēklu plantācijām: J. Gailis (1964), A. Kundziņš (1953), Dz. Pīrāgs (1968), V. Rone (1983), Bušs, M. un I. Mangalis (1971).

${ }^{35}$ Bušs 1960; Bušs, Mangalis 1971; Kundziṇš, Cinītis 1979.

36 Daugaviete et al. 2017.

37 Turpat.; Gailis 1964; Bušs, Mangalis, 1971; Pīrāgs 1968; Kundziṇš 1953.

38 Turpat.
Tiek izstrādātas jaunas priežu un citu kokaugu potēšanas metodes, izzinātas parastās egles pavairošanas iespējas ar spraudeņstādiem: V. Rone, V. Bambe, I. Vēveris, kā arī pētīta stādu izaudzēšana no atlasīta, selekcionēta sēklu materiāla: I. Mangalis (2004), M. Bušs, I. Tjarve, G. Igaunis u. c.

İpaši apsekoti ieaudzēto koku sugu ǵenētiskie un stumbru kvalitātes rādītāji: J. Matuzānis, J. Bisenieks, I. Tjarve, R. Sacenieks ${ }^{39}$.

Ievērojami uzlabotas un pilnveidotas arī stādmateriāla izaudzēšanas tehnolog̣ijas un uzsākta visām sezonām piemērota stādmateriāla - ietvarstādu jeb konteinerstādu - ražošana dažāda izmēra kasetēs: M. Bušs, J. Broks, A. Rubene, A. Šveice u. c. ${ }^{40}$

Fundamentāli pētījumi par egḷu plantāciju ierīkošanu auglīgajos meža tipos, kā arī nosusinātos kūdrājos veikti zinātnes un ražošanas apvienībā (ZRA) Silava (no 1992. gada Latvijas Valsts mežzinātnes institūts [LVMI] Silava $)^{41}$.

\section{Mežaudze un plantāciju mežs kā zemes racionālas apsaimniekošanas veids}

Jautājums par zemes racionālu izmantošanu atkārtoti aktualizējās 20. gs. 90. gados, kad atjaunotajā Latvijas brīvvalstī pēc agrārās reformas 36,6\% lauksaimniecības zemju un $42 \%$ meža zemju nonāca privātīpašnieku pārziņa ${ }^{42}$. Attīstoties tirgus ekonomikai, daudzās mazvērtīgajās lauksaimniecības zemēs produktu ražošana kḷuva nerentabla un zeme tika atstāta atmatā. Sākās lielu platību dabiska apmežošanās, un radās nepieciešamība šo jomu sakārtot. Pamatojoties uz Saeimas Tautsaimniecības, agrārās un reǵionālās politikas komisijas prasību par lauksaimniecībā neizmantoto zemju apgūšanas perspektīvām, 1993. gada 27. decembrī nāk klajā Valsts meža dienesta (VMD) speciālistu ziņojums (Nr. 03-10.1/784) par šo zemju apmežošanas iespējām un arī vairāki ieteikumi - sākotnēji lauksaimniecības zemēs

\footnotetext{
${ }^{39}$ Daugaviete et al. 2017; Gailis 1964; Bušs, Mangalis, 1971; P̄̄rāgs 1968; Kundziṇš 1953.

40 Turpat.

${ }^{41}$ LVMI Silava Vēsture 2019.

${ }^{42}$ Lauksaimniecībā izmantojamās zemes izmantošana 2016.
} 
veidojama "meža" vide, stādot lapu kokus: ozolu, osi, bērzu, melnalksni, baltalksni, apsi.

1995. gadā LVMI Silava ar VMD atbalstu iesaistījās Phare projekta Tehniskā palīdzība privātmežu apsaimniekošanai Latvijā izpildē un uzsāka pētījumus par lauksaimniecībā neizmantojamo zemju apmežošanu un apmežošanas modelı izstrādi ${ }^{43}$.

Projekta izpildes gaitā LVMI Silava zinātnieki, apkopojot agrāk veikto pētījumu rezultātus, izstrādāja izpētes programmas pamatojumu meža ieaudzēšanai nemeža zemēs, izvirzot šādus darba uzdevumus:

- izvēlēties meža un kokaugu (plantāciju) audzēšanai piemērotas zemju platības Latvijas reǵionos, ņemot vērā zemes auglību un lauksaimniecības attīstības perspektīvas, apdzīvotību, teritorijas ekoloǵisko stāvokli, tās ainavisko plānojumu, kultūrvēsturiskās tradīcijas u. c. faktorus;

- izvērtēt kokaugu (meža un plantāciju) audzēšanai paredzēto platību piemērotību dažādu koku sugu audzēšanai, ņemot vērā biotiskos un abiotiskos apstākḷus;

- izstrādāt rekomendācijas apmežojamo platību ražības paaugstināšanai, kā arī nemeža zemju transformēšanai meža zemēs;

- pamatojoties uz koksnes un nekoksnes produkcijas patēriņa aplēsēm, augsnes piemērotību un platību ekologisko un ainavisko vērtējumu, noteikt dažādos valsts reǵionos audzējamo sugu sastāvu un platības, lai prognozētu nepieciešamo reproduktīvā materiāla daudzumu;

- izstrādāt un aprobēt zinātniski pamatotu metodiku teritorijas ekologisko un hidroloǵisko parametru prognozēšanai saistībā ar platību apmežošanu;

- izstrādāt zinātniski pamatotu audzējamo sugu reproduktīvā materiāla (sēklu, stā$\mathrm{du}$ ) ieguves programmu;

- izstrādāt lauksaimniecībā neizmantojamo zemju apmežošanas ekonomisko pamatojumu.

No 1995. līdz 2015. gadam veikti pêtījumi par mežaudžu augšanas gaitu bijušajās lauksaimniecības platībās, izvērtējot parastās egles, priedes, bērza, melnalkšṇa, baltalkšṇa u. c. audžu augšanas gaitu un stumbru kvalitāti

43 Daugaviete et al. 2017. jaunajos un iepriekšējo gadu stādījumos ${ }^{44}$. Pētījumos konstatēts, ka vienāda vecuma bērza, parastās egles un priedes, baltalkšņa audžu krājas gan meža, gan lauksaimniecības zemēs būtiski neatšksiras. Tomēr zinātnieki secināja, ka bijušajās lauksaimniecības zemju audzēs I vecumklasē (1-20 gadi) augstāki augšanas gaitas rādītāji (vidējais augstums, vidējais caurmērs, kārtējais krājas pieaugums) ir audzēm bijušajās lauksaimniecības zemēs, savukārt nākamajās vecumklasēs augšanas gaitas atškirīibas izlīdzinās. Galvenais iemesls - mūsdienu meži pārsvarā ir stādīti un lietotais stādmateriāls izaudzēts no atlasītu audžu sēklām. Pētījumā Lauksaimniecības zemju apmežošana ar bērzu - sagaidāmā koksnes kvalitāte un ekonomiskā efektivitāte secināts, ka bērzu audžu augšanas gaita bijušajās lauksaimniecības zemēs ir salīdzināma ar labāko bonitāšu dabisko mežaudžu augšanas gaitu. Netika konstatēts, ka bērzu augšanas gaita lauksaimniecības augsnēs šajā ziņā ievērojami pārsniegtu dabisko mežaudžu rādītājus; būtiska audžu produktivitātes palielināšanās panākama, tikai uzlabojot apsaimniekošanas metodes ${ }^{45}$.

Pētījumi turpinās, jo norises dabā un stādījumu ierīkošanas tehnolog̣ijas ir būtiski mainījušās. Pēdējā desmitgadē Latvijā sakarā gan ar klimata izmain̄ām un zemes racionālas apsaimniekošanas pamatnostādnēm, gan plantāciju mežu, īscirtmeta plantāciju un kokaugu stādījumu audzēšanas noteikumu ieviešanu, gan stādmateriāla izaudzēšanas apjoma un kvalitātes uzlabošanos zinātnieki padziḷināti pētījuši mežaudžu produktivitāti un veselīgumu apmežotajās lauksaimniecības zemēs un izvērtējuši š̄s audzes, augstražīgu plantāciju mežu ierīkošanas un apsaimniekošanas tehnoloǵijas - tiek pētīta šo plantāciju ietekme uz vidi, kā arī plantāciju mežos izaudzētās koksnes kvalitāte, lietojamība tautsaimniecībā un plantāciju mežu audzēšanas ekonomiskā efektivitāte ${ }^{46}$.

Bērza finierkluču audzēšanas programmas īstenošanu 1996. gadā uzsāka un tās izpildē

44 Dreimanis 2001; Liepiņš 2005; Liepiņš 2006; Miezīte, Dreimanis 2007; Daugaviete et al. 2017.

${ }^{45}$ Liepiṇš 2006.

${ }^{46}$ Daugaviete et al. 2017. 


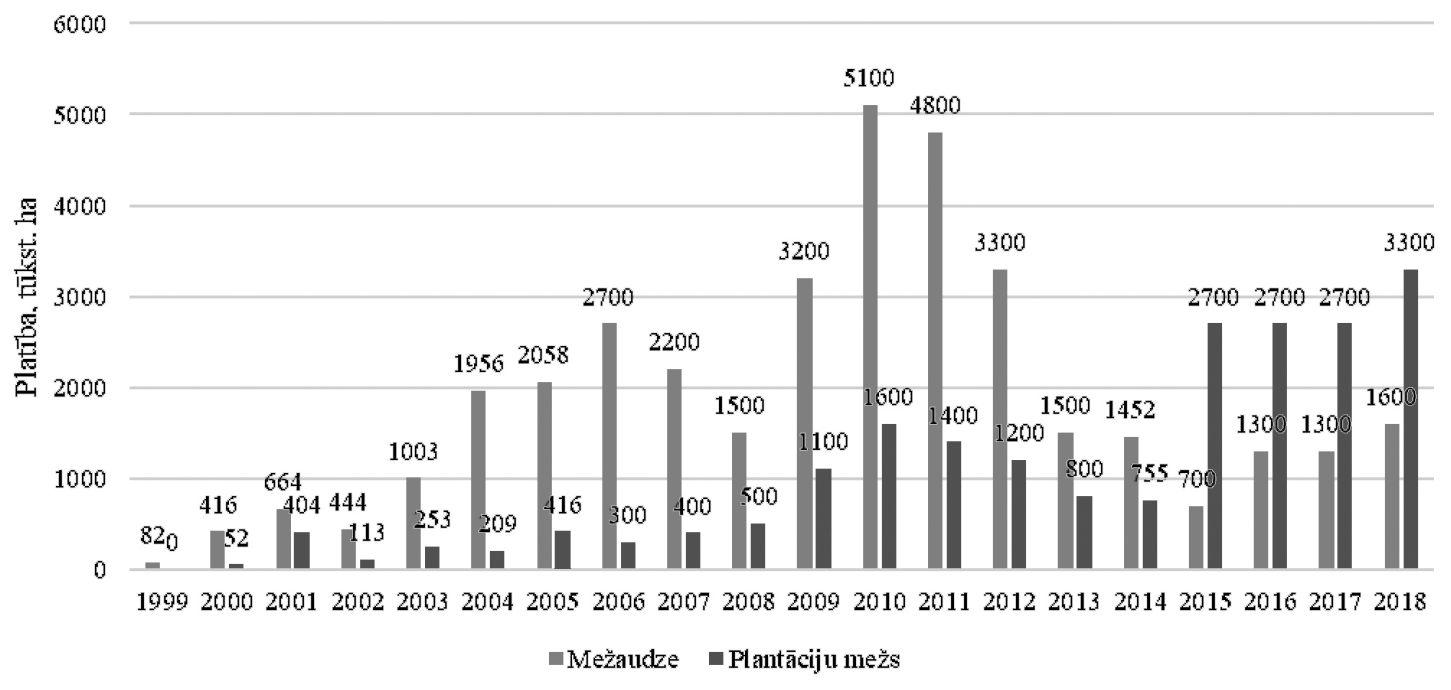

5. attēls. Meža ieaudzēšana Latvijā 1999.-2018. gadā. Avots: www.vmd.gov.lv

aktīvi iesaistījās privātā akciju sabiedrība Latvijas Finieris (LF), kuras darbības sfērā ietilpa iepirkto meža īpašumu apsaimniekošana, neizmantoto lauksaimniecības zemju apmežošana, galvenokārt ar bērzu, kā arī šo apmežojumu kopšana. Lai nodrošinātu LF vajadzības pēc finierklučiem, Bērzu programmai bija šādi galvenie uzdevumi:

- atrast piemērotāko koku sugu lauksaimniecībā neizmantoto zemju apmežošanai un apgūt tās audzēšanas īpatnības;

- iegūt kvalitatīvu bērzu audzi un palielināt bērzu audžu platības Latvijā;

- popularizēt bērzu audzēšanu ${ }^{47}$.

Izvirzīto uzdevumu veikšanai LF piesaistīja šādus sadarbības partnerus: VMD, Meža pētīšanas staciju, LVMI Silava, LLU Meža fakultāti, Latvijas Valsts koksnes ķīmijas institūtu (LVKK̦I), mežu privātīpašniekus, valsts akciju sabiedrību Latvijas valsts meži. Šo partneru zināšanas un kvalifikācija garantēja paredzēto pētījumu un pasākumu sekmīgu izpildi. Galvenie ieguvumi, kā uzskata SIA Latvijas Finieris Mežs, ir kvalitatīvi veikti bērzu stādījumi, bērzu audzēšana pēc jaunām tehnolog̣ijām, bērzu jaunaudžu un bērza koksnes īpašību

${ }^{47}$ Stādīsim bērzu 2006. zinātniskie pētījumi, bērzu stādīšana un mežu atjaunošana ${ }^{48}$. Sākot ar 1996. gadu, AS Latvijas Finieris uzn̄ēmums SIA Latvijas Finieris Mežs izsludina akciju Kvalitatīvu bērzu audzēšanas programma ilgtermin,ā. Īpašnieki varēja pieteikties bērzu stādiem un audžu kopšanas programmai (bija paredzēta līdz 2015. gadam) un pretendēt uz atbalstu 2-5 ha liela bērzu stādījuma izkopšanai ${ }^{49}$.

No 1999. līdz 2018. gadam apmežoto lauksaimniecības zemju platības ar stādāmo materiālu no atlasītu koku sugām sasniegušas 58,1 tūkst. ha, ieskaitot plantāciju mežus 20,9 tūkst. ha (34\% no apmežotajām platībām) (5. attēls). Zīmīgi, ka plantāciju mežu platības, sākot ar 2015. gadu, ievērojami augušas un pārsniedz ieaudzēto mežaudžu platības. Tas liecina, ka Latvijas mežkopji iet laikam līdzi un izvēlas plantāciju mežu kā ekonomiski izdevīgu lauku apsaimniekošanas veidu.

Mežzinātnieki aktīvi strādā, selekcionējot ātraudzīgu koku sugas - apšu hibrīdus ${ }^{50}$, papeḷu klonus ${ }^{51}$, kārklu šķirnes ${ }^{52}$ - un veidojot un ekonomiski novērtējot kokaugu plantācijas.

Jautājums par zemes racionālu izmantošanu ir aktuāls arī mūsdienās. Pamatojoties

\footnotetext{
48 Dreimanis, 2001; Zālītis et al. 2003; Zālītis 2008; Zālītis, Jansons 2014.

49 Akcija - stādi 2015.
} 
uz LVMI Silava izstrādāto programmu par lauksaimniecībā neizmantojamo zemju apmežošanas problēmu risināšanu, kā arī pateicoties ES fondu līdzekliem un daḷēji arī Zemkopības ministrijas un Latvijas valsts mežu atbalstam, no 1993. līdz 2018. gadam LVMI Silava veica pētījumus, kas aptvēra visus programmā paredzētos darba uzdevumus, īpašu uzmanību pievēršot kokaugu plantāciju un plantāciju mežu izvērtējumam, lietojot dažādas kokaugu sugas $^{50}$.

\section{Secinājumi}

1. Meža platības Latvijā laika posmā no 1923. gada līdz 2018. gadam palielinājušās par 563 tūkst. ha un sasniegušas 3,383 milj. ha.

${ }^{50}$ Zālītis 2012; Jansons 2014; Daugaviete et al. 2017; Zālītis 2006; Zeps et al. 2012.

${ }^{51}$ Lazdina, Daugaviete 2010 .

${ }^{52}$ Lazdiṇa, Lazdiṇš 2011.
2. Latvijas valsts mežainums 2018. gadā sasniedzis $52 \%$ no visas valsts teritorijas.

3. Pirmajā Latvijas neatkarības posmā (1918-1940) valsts ekonomiskā stāvokḷa uzlabošanai sākās nemeža zemju apmežošana: kāpu apmežošana, neizmantojamo lauksaimniecības zemju apmežošana, vējlauzēja joslu un aleju ierīkošana.

4. Sekmīgai uzdevuma izpildei 1930. gadā tika iedibinātas Meža dienas, kuras katru gadu notiek arī tagad.

5. Mežzinātnieku ieguldījums mežaudžu uzlabošanā: dažādu koku sugu augšanas gaitas un apsaimniekošanas pētījumi, selekcijas pētījumi, atlasot perspektīvākos klonus un izveidojot sēklu plantācijas, izstrādājot tehnoloǵijas dažādu augšnu, kā arī kāpu apmežošanai, ievērojami uzlabotas un pilnveidotas stādmateriāla izaudzēšanas tehnologijijas, sākot no sēklu ieguves līdz gatavam stādam, kokaugu plantāciju un plantāciju mežu ierīkošanas tehnologijas un ekonomiskie ieguvumi.

\section{VĒRES}

Akcija - stādi (2015) Pieejams: www.lfmezs.lv (15.04.2014.).

Bērziṇš, P. (1930) Vairosim zaḷā zelta krājumus. Meža Dzīve, 56 (aprīlis), 1993-1994.

Bērza nozīme un ieaudzēšana (1934) Priekšlasījums radiofonā (09.05.1934.). Meža Dzīve, 106 (jūnijs), $3776-3781$.

Birnbaums, K. (1936) Gadu maiņā. Meža Dzīve, 125 (janvāris), 4432-4434.

Birnbaums, K. (1936a) Rīkosim meža dienas! Meža Dzīve, 128 (aprīlis), 4539-4541.

Birnbaums, K. (1937) Meža dienas Latvijā 1937. gadā. Mežsaimniecības rakstu krājums, XV, 194-205.

Brīvkalns, K. (1959) Latvijas PSR augsnes. Rīga : Latvijas Valsts izdevniecība.

Bruttans, R. (1928) Mākslīgas mežu atjaunošanas rezultāti Skrīveru novadā. Mežsaimniecības rakstu krājums, VI, 103-109.

Bušs, M. (1960) Latvijas kāpu smiltāji un to apmežošana. Rīga : Latvijas Valsts izdevniecība.

Bušs, M.; Mangalis, I. (1971) Meža kultūras. Rīga : Zvaigzne.

Daugaviete, M.; Bambe, B.; Lazdiņ̌̌, A.; Lazdiṇa, D. (2017) Plantāciju mežu augšanas gaita, produktivitāte un ietekme uz vidi. Salaspils, Daugavpils : LVMI Silava, DU akadēmiskais apgāds "Saule".

Dreimanis, A. (2001) Pētījumi par kopšanas ietekmi uz bērzu kvalitāti dabiski veidojušās audzēs. $L L U$ raksti, 47-77.

Eihe, V. (1933) Mežu tipi kā mežu vēsturiskās izveidošanās rezultāts. Mežsaimniecības rakstu krājums, 39-48.

Eihe, V. (1935) Meža augsnes un vinuu pārveidošanās. Mežsaimniecības rakstu krājums, XIII, 150-167.

Eihe, V. (1937) Cilvēka loma Latvijas meža izveidošanas gaitā. Mežsaimniecības rakstu krājums, XV, $134-146$.

Gailis, J. (1964) Meža koku selekcija un sēklu plantācijas. Rīga : Latvijas Valsts izdevniecība. 
Galeniece, M. (1935) Latvijas purvu un mežu attīstība pēcledus laikmetā. Latvijas Universitātes Raksti: Lauksaimniecības fakultātes sērija, II (20), 582-646.

Galeniece, M.; Tabaka, L.; Birkmane, K. (1958) Latvijas PSR veǵetācija. Rīga : Latvijas PSR Zinātņu akadēmijas izdevniecība.

Gross, O. (1936) Bērza koksnes izmantošana un apstrādāšana finieru rūpniecībā. Mežsaimniecības rakstu kräjums, XIV, 88-109.

Jakobsons, A. (1932) Bērzu noderīgums finieru rūpniecībā. Mežsaimniecības rakstu krājums, X, 47-55.

Jansons, J. (red.) (2014) Četri mežzinātņu motīvi. Salaspils, Daugavpils : LVMI Silava, DU akadēmiskais apgāds "Saule".

Jurēvičs, B. (1927) Ozolu kultūras un audzes. Mežsaimniecības rakstu krājums, XV, 53-77.

Jurēvičs, B. (1931) Meža atjaunošana, piemērojoties dažādām augsnēm. Rīga : Mežu departaments.

Kiršteins, K. (1923) Mežaudžu asociācijas kā mūsu mežu klasifikācijas pamats. Mežsaimniecības rakstu krājums, 1-21.

Kiršteins, K. (1936) Ozols (Quercus robur L.) Kurzemē. Mežsaimniecības rakstu krājums, 43-75.

Kundziņš, A. (1953) Priežu un alkšņu mistrotās audzes vājās smilts augsnēs. ZA Vēstis, 4.

Kundziņš, A.; Cinītis, O. (1979) Par melnalkšņa nākotni mūsu mežos. Mežsaimniecība un mežrūpniecība, $5,11-12$.

Latvijas biotopi (2001) Rīga : Latvijas Dabas fonds.

Latvijas mežu vēsture (2014) Pieejams: http://latvijas.daba.lv/biotopi/mezi.shtml (20.10.2019.).

Lauksaimniecībā izmantojamās zemes izmantošana (2016) Latvijas statistikas gadagrāmata 2015. Rīga : Centrālā statistikas pārvalde.

Lazdiņa, D.; Bačkaitis, J.; Gruduls, K.; Kal̦einikovs, K. (2012) The establishment of energy wood plantations: Manual for farmers - the beginners in energy wood plantation. Šiauliai, Jelgava.

Lazdina, D.; Daugaviete, M. (2010) Short rotation woody energy crops in Latvia. Fifth International Scientific Conference Students on Their Way to Science: Collection of Abstracts. Jelgava, 30-40.

Lazdiṇa, D; Lazdiņš, A. (2011) İscirtmeta kārklu plantācijas un to izmantošanas iespējas. LVMI Silava, 36.

Lazdiņš, A. (2011) Dabiski apmežojušos lauksaimniecības zemju efektīvas apsaimniekošanas nosacījumi: Promocijas darba kopsavilkums. Jelgava : LLU.

Liepa, I.; Mauriņš, A.; Vimba, E. (1991) Ekologija un dabas aizsardzība. Rīga : Zvaigzne.

Liepiņš, K. (2005) Pārskats: Līguma Nr. 240206/C-54 Mežaudžu kvalitāte apmežojumos bijušajās lauksaimniecības platībās. Salaspils : LVMI Silava.

Liepiņš, K. (2006) Pārskats: Līguma Nr. 240206/C-54 Lauksaimniecības zemju apmežošana ar bērzu - sagaidāmā koksnes kvalitāte un ekonomiskā efektivitāte. Salaspils : LVMI Silava.

LVMI Silava Vēsture (2019) Pieejams (20.10.2019.): http://www.silava.lv/main/par-instittu/vsture.aspx.

Mangalis, I. (2004) Meža atjaunošana un ieaudzēšana. Rīga : Et Cetera.

Mežsaimniecības stāvoklis bijušajās Baltijas provincēs: Statistiskie dati (1931) Mežsaimniecības rakstu krājums, IX, 72.

Miezīte, O.; Dreimanis, A. (2007) Productivity of Grey Alder (Alnus incana (L.) Moench) Stands. Research for Rural Development 2007: International Scientific Conference Proceedings, Jelgava, 16-17 May 2007, Latvian University of Agriculture. Jelgava, 174-180.

Ozols, J. (1926) Mežsaimniecības apstākḷi Latvijā. Mežsaimniecības rakstu krājums, IV, 79-90.

Ozols, J. (1936) Finierrūpniecības izveidošanās. Mežsaimniecības rakstu krājums, XIV, 82-87.

Ozols, J. (1937) Pārskats par valsts mežsaimniecību un Mežu departamenta darbību no 15.V 1934.-15.V 1937. g. Mežsaimniecības rakstu krājums, XV, 3-17.

Pīrāgs, Dz. (1968) Duglāzija. Rīga : Zinātne, 130.

Plūmanis, A. (1935) Bērzu gatves lai kḹūst par tautas vienojošo saiti. Meža Dzīve, 117 (maijs), 4156.

Priedītis, N. (2014) Latvijas augi. Rīga : Gandrs.

Reinholds, J. (1933) Kūdrāju apmežošana. Meža Dzīve, 90 (februāris), 3281-3283.

Reinholds, J. (1935) Mežu atjaunošana. Mežsaimniecības rakstu krājums, XIII, 107-117. 
Reinholds, J. (1937) Ventspils-Liepājas rajona meža zemju apmežošana. Mežsaimniecības rakstu krājums, $\mathrm{XV}, 77-98$.

Rone, V. (1983) Tehniskie norādījumi eglı īscirtmeta plantāciju projektēšanai un ierīkošanai Latvijas PSR. Salaspils : ZRA Silava.

Roze, E. (1933) Bērzs un viņa atjaunošana. Mežsaimniecības rakstu krājums, XI, 10-16.

Roze, E. (1939) No laba sēklas materiāla līdz augstvērtīgai meža ražai. Mežsaimniecības rakstu krājums, XVII, 90-109.

Rudzītis, J. (1979) No Vijciema mežsaimniecības vēstures. Meža Vēstis, 171, $27-29$.

Saliņš, Z. (1999) Meža izmantošana Latvijā. Jelgava : LLU Meža izmantošanas katedra, 270.

Sarma, P. (1949) Pētījumi par priežu un egḷu audžu augšanas gaitu tîrumu augsnēs. Latvijas PSR Zinātṇu Akadèmijas Vèstis, 7, 24, 31-42.

Stādīsim bèrzus (2006) Rīga : Latvijas Finieris, 27.

Strods, H. (red., sast.) (1999) Latvijas mežu vēsture līdz 1940. gadam. Rīga : Pasaules Dabas fonds.

Teikmanis, A. (1931) Meža dienas Latvijā 1931. gadā. Mežsaimniecības rakstu krājums, IX, 139-193.

Ulmanis, K. (1935) Lai dzīvie pieminekḷi izaugtu kā liecinieki mūsu darbam: Ministru Prezidenta meža dienu atklāšanas runa 1935. g. 20. aprīlì. Meža Dzīve, 116 (aprīlis), 4120-4124.

Upīts, H. (1931) Pamācība meža atjaunošanai. Rīga : Meža departaments.

Vasiḷevskis, A. (2007) Latvijas valsts mežu apsaimniekošana 1918-1940. Rīga : Nacionālais apgāds.

Vītiņš, J. (1925) Kādi bijuši agrāk mūsu meži un mežu zemes? Mežsaimniecības rakstu krājums, III, 3-17.

Zālītis, P. (2006) Mežkopības priekšnosacījumi. Rīga : Et Cetera.

Zālītis, P. (2012) Mežs un ūdens. Salaspils : LVMI Silava.

Zālītis, P.; Dreimanis, A.; Daugaviete, M. (2003) Bērza audžu kopšana. Rīga : Latvijas Finieris.

Zālītis, P.; Jansons, J. (2014) Salikto bērza audžu ražǐba un to apsaimniekošanas režīms. Jansons, J. (red.) Četri mežzinātñu motīvi. Salaspils, Daugavpils : LVMI Silava, DU akadēmiskais apgāds "Saule", 37-78.

Zālīitis, P.; Lībiete, Z.; Zālīitis, T. (2006) Mērḳtiecīgi izveidoto kokaudžu augšanas gaita un strukturēšanās. Mežzinātne, 16, 49, 9-20.

Zālītis, T. (2008) Kārpainā bērza (Betula pendula Roth.) augšanas gaita un stumbra kvalitāti ietekmējošie faktori auglīgajos meža tipos Latvijā: Promocijas darba kopsavilkums Dr. silv. zin. grāda iegūšsanai. Jelgava : LLU.

Zeps, M.; Auzenbaha, D.; Gailis, A.; Treimanis, A.; Grīnfelds, U. (2008) Hibrīdapšu (Populus tremuloides $\times$ Populus tremula) klonu salīdzināšana un atlase. Mežzinātne, 18, 51, 19-34.

Zeps, M.; Šāble, I.; Grīnfelds, U.; Jansons, Ā.; Irbe, I.; Treimanis, A. (2012) Apšu hibrīdu (Populus tremuloides Michx. $\times$ Populus tremula L.) un parastās apses (Populus tremula $\mathrm{L}$.) koksnes un sulfătcelulozes šķiedru īpašības 20 gadu vecumā. Mežzinātne, 26, 145-154.

Zunde, M. (1999) Mežainuma un koku sugu sastāva pārmaiņu dinamika un to galvenie ietekmējošie faktori Latvijas teritorijā. Strods, H. (red., sast.). Latvijas mežu vēsture lìdz 1940. gadam. Rīga : Pasaules Dabas fonds, 111-206. 